\title{
An Inclusive Study on the Effect of Strain Rate on the Stress-Strain Behavior and the Undrained Shear Strength of Clay Soils in Kombolcha, Ethiopia
}

\author{
Salman Mohammed \\ Faculty of Civil Engineering \\ Arba Minch Institute of Technology \\ Arba Minch, Ethiopia \\ salmanmohammed872@gmail.com \\ Ramesh K. Verma \\ Faculty of Civil Engineering \\ Arba Minch Institute of Technology \\ Arba Minch, Ethiopia \\ vermark42@gmail.com
}

\author{
Democracy D. Dirate \\ Faculty of Civil Engineering \\ Arba Minch Institute of Technology \\ Arba Minch, Ethiopia \\ democracy.dilla@amu.edu.et
}

\author{
Vasudeva R. Pampana \\ Faculty of Civil Engineering \\ Arba Minch Institute of Technology \\ Arba Minch, Ethiopia \\ vasudevarao_9@yahoo.com
}

\author{
Defaru K. Dasho \\ Faculty of Civil Engineering \\ Arba Minch Institute of Technology \\ Arba Minch, Ethiopia \\ defaru.katise@amu.edu.et \\ Ruth B. Sangalang \\ Faculty of Civil Engineering \\ Arba Minch Institute of Technology \\ Arba Minch, Ethiopia \\ ruthie_sang@yahoo.com
}

\author{
Abera E. Koshuma \\ Faculty of Hydraulics and Water Resource Engineering \\ Arba Minch Water Technology Institute \\ Arba Minch, Ethiopia \\ abera.ermias@amu.edu.et
}

\author{
Abebe T. Ayalew \\ Faculty of Hydraulics and Water Resource Engineering \\ Arba Minch Water Technology Institute \\ Arba Minch, Ethiopia \\ abebe.temesgen@amu.edu.et
}

\begin{abstract}
This research aims to study the effect of strain rate on the stress-strain association and shear strength of clay soils in Kombolcha, Ethiopia. Field and laboratory experimentations were conducted on 3 soil samples collected at $4.5 \mathrm{~m}$ depth, considering the physical and engineering properties of the soil. Unconsolidated, undrained triaxial compression tests were performed under confining pressure on the specimens that were axially loaded at a rate of strain varying from $0.38 \mathrm{~mm} / \mathrm{min}$ to $1.14 \mathrm{~mm} / \mathrm{min}$ by taking 2 points above and below $1 \%$ of the specimen height. Stress-strain relations were developed under the stated different rates of strains to describe their effect. It was revealed that the strain rate effect was observed. By increasing the strain rate shifts the stress-strain curve upward, and the corresponding shear strength of the soil also increased under effective stress. Accordingly, the strain rate increased the shear parameters. The average angle of friction increased by $13.43 \%$, $15.08 \%, 13.18 \%$, and $14.33 \%$ when the rate of strain changed from 0.38 to $0.57 \mathrm{~mm} / \mathrm{min}, 0.57$ to $0.76 \mathrm{~mm} / \mathrm{min}, 0.76$ to $0.95 \mathrm{~mm} / \mathrm{min}$, and 0.95 to $1.14 \mathrm{~mm} / \mathrm{min}$ respectively, while the average cohesion increased by $17.67 \%, 19.52 \%, 14.87 \%$, and $16.48 \%$. The failure at strain rate $1 \% / \mathrm{min}$ of sample height $(0.76 \mathrm{~mm} / \mathrm{min})$ was uniformly distributed and there was uniform pore pressure distribution throughout the sample height. The effect is slightly more when the shear strength increased at the left side than at the right side. Average shear strength parameters such as cohesion and angle friction were recorded for strain rates from $0.57 \mathrm{~mm} / \mathrm{min}$ to $1.25 \mathrm{~mm} / \mathrm{min}$ specifically for the clay soils found in Kombolcha town, Ethiopia.
\end{abstract}

Keywords-inclusive study; rate; strain; shear; soil

\section{INTRODUCTION}

Investigation on the properties of soil is significant in designing and building structures with foundations secured by materials such as soils and/or rocks. Soils have a maximum shearing resistance that they can sustain to the applied shear stress, which is a function of the effective normal stress that can determine its magnitude [1]. Shearing resistance is developed by friction, interparticle forces, cementation, or bonding at particle contacts, therefore, if the effective normal stress is zero, then the shearing resistance must be zero (unless there is cementation between the particles). If at a point on any plane within a soil mass the shear stress becomes equal to the shear strength of the soil then failure will occur. One of the factors that affect the shear strength of the soil is the strain rate [2]. The strength of saturated clay, as observed in undrained shear tests increases with the increasing strain rate [3-5]. The peak shear resistance increases from slow to fast strain rate.

Small strains occur from increased strength in terms of effective stress, and large strains from decreased excess pore pressure $[6,7]$. Increasing the strain rate applied to a saturated soil means larger effective stresses and consequently greater shear resistance [8]. At large strains, the relationship between void ratio and effective stress is strain-rate dependent. As the strain-rate is increased, larger effective stress is required to 
hold the soil at any given void ratio [9]. At faster strain rates, adjacent soil particles find it more difficult to move relatively, and, unless restrained by increased effective stress, will tend to ride up over one another. The measured pore water pressure is smaller at fast than at slow strain rate. The behavior of the pore pressure following a sudden increase in the strain rate proves that there is fundamentally an inverse relationship between the strain rate and the excess pore pressure [10-12]. The effect of strain rate on the stress-strain relationship and shear strength of clay by conducting a series of triaxial compression tests on remolded soil samples prepared with $38 \mathrm{~mm}$ diameter and height of twice the diameter was studied in[13-15]. The type of triaxial test employed was Consolidated Undrained (CU) test with pore pressure measurement and by using different effective consolidation pressures. The specimens were axially loaded at a rate of strain varying from $0.001 \mathrm{~mm} / \mathrm{min}$ to $2 \mathrm{~mm} / \mathrm{min}$. The results show that the strain rate affects both the stress-strain relationship and the strength of the soil. As the strain rate increases, the strength of the soil also increases, but the strain rate has a more pronounced effect on the cohesion and little effect on the angle of internal friction of the soil [16].

In this research, Unconsolidated Undrained (UU) triaxial test was used to measure the undrained shear strength of clay soil from Kombolcha. The soil in the town is dominantly finegrained, belonging in the clay group. The aim of this research is to set quick and convenient UU shear tests for the clay soils found in the study area and to determine the best strain rate for the elastic and shear strength behaviors of soils [17]. Kombolcha is an industrial and grooming town that has seen increase in its infrastructures. The town is found in the Eastern part of the Amhara region, Ethiopia, and is located about $375 \mathrm{~km}$ north of the state capital, Addis Ababa, along the road to Mekelle and $23 \mathrm{~km}$ southeast of Dessie city. It is situated on the western margin of the Main Ethiopian Rift valley and covers an area of about $120 \mathrm{~km}^{2}$. Soils found in this town belong mostly to the fine-grained clay class [18].

\section{RESEARCH METHODOLOGY}

To achieve the study goals, 8 soil samples were collected from Kombolcha at a depth of $4.50 \mathrm{~m}$ from the ground surface. From the samples, 3 were nominated to represent the other 5 samples according to their physical properties. The remolded clay specimens were prepared and used in the laboratory [19]. The selected samples' locations are presented in Table I.

Moisture content and field densities of the 3 pits were determined in the field and the samples were transported to the laboratory while they were kept in a plastic bag to prevent moisture loss. The measured amount of the wet soil was put in a conventional oven of $105^{\circ} \mathrm{C}$ and kept for 24 hours and was examined to determine its weight loss in order to the determine moisture and density of the collected soils [20].

TABLE I. TEST PIT LOCATION AND COORDINATES OF THE STUDY AREA

\begin{tabular}{|c|c|c|c|}
\hline Pit No. & Location & Latitude (DMS) & Longitude (DMS) \\
\hline Pt-1 & Kurangoye & $11^{\circ} 5^{\prime} 27.59^{\prime \prime}$ & $39^{\circ} 43^{\prime} 11.64^{\prime \prime}$ \\
\hline Pt-2 & Elkbeye & $11^{\circ} 4^{\prime} 48.36^{\prime \prime}$ & $39^{\circ} 42^{\prime} 50.76^{\prime \prime}$ \\
\hline Pt-3 & Sheshaber & $11^{\circ} 5^{\prime} 27.59^{\prime \prime}$ & $39^{\circ} 42^{\prime} 35.64^{\prime \prime}$ \\
\hline
\end{tabular}

\section{A. Soil Grain and Consistency Limit Test}

Sieve analysis was performed to determine the distribution of the course, larger-sized particles, and hydrometer test was conducted for 24 hours to determine the distribution of finer particles (less than $0.075 \mathrm{~mm}$ ). Two jars with $1000 \mathrm{ml}$ capacity were used. A control jar with distilled water and $5 \mathrm{~g}$ of sodium hexametaphosphate was used as a dispersing agent and the other was a soil sample with distilled water and $5 \mathrm{~g}$ of dispersing agent. A mechanical stirrer was also used for mixing the soil samples with distilled water and the dispersing agent. Soils passing through a $0.425 \mathrm{~mm}$ sieve were used to determine the plastic and liquid limits of fine-grained soil. The specimens were soaked for 30 minutes and mixed for 5 minutes [21-23].

\section{B. Specific Gravity and Free Swell Determination Tests}

The specific gravity of the samples was determined with the help of a pycnometer using a soil sample that passed through the $2 \mathrm{~mm}$ sieve. The sample was connected to the hydrometer and was oven-dried at $105^{\circ} \mathrm{C}$. A minimum soil sample of $20 \mathrm{~g}$ was used [24]. Free swell index is the increase in the volume of soil, without any external constraints, on submergence in water. Representative oven-dried soil samples having mass of $10 \mathrm{~g}$ passing through $0.425 \mathrm{~mm}$ sieve were put in $100 \mathrm{ml}$ of water in a jar for 24 hours. Swelling was examined as a percentage of the volume change to the original volume $[25,26]$.

\section{Compaction Test}

Laboratory compaction procedures were used to determine the relationship between water content and the dry unit weight of soils. The soil samples were compacted in 3 layers with a $24.4 \mathrm{~N}$ rammer dropped from a height of $305 \mathrm{~mm}$ producing a compactive effort of $600 \mathrm{kN}-\mathrm{m} / \mathrm{m}^{3} .8 \%$ of $3000 \mathrm{~g}$ of the test sample were added in $\mathrm{mm}$ as the initial water content and $4 \%$ water content increments were used to obtain a well-defined maximum dry unit weight. After obtaining the density and moisture of each compacted soil sample, Maximum Dry Density (MDD) and Optimum Moisture Content (OMC) were determined from the compaction curve $[27,28]$.

\section{Consolidation and Permeability Test}

This test was performed to determine the magnitude and rate of volume decrease a laterally confined soil specimen undergoes when subjected to different vertical pressures. From the measured data, the consolidation curve (pressure-void ratio relationship) can be plotted. These data are useful in determining the compression index and the recompression index of the soil. Besides, the obtained data can also be used to determine the coefficient of consolidation and the coefficient of secondary compression of the soil. Tests were carried on the undisturbed samples by pushing the consolidation ring into the ground at a depth of $4.50 \mathrm{~m}$ during the sample collection. The samples were transported to the laboratory while they were kept in a plastic bag. Soil samples with diameter of $63 \mathrm{~mm}$ and height of $20 \mathrm{~mm}$ were loaded with pressures from $7 \mathrm{kPa}$ to $1600 \mathrm{kPa}$. For each loading the compression was recorded from the dial gauge at intervals of $0.1,0.25,0.5,1,2,4,8,15,30$, $60,120,240,480$, and 1440 minutes for 24 hours. Unloading to examine unloading behavior was also done in steps. A total of 3 consolidation tests were run on undisturbed samples and different results were obtained. From the test results of the 
consolidation curve (pressure-void ratio relationship), compression index (Cc) and expansion index (Ce) were determined [29]. The purpose of the permeability test is to determine the permeability (hydraulic conductivity) of the soil by the falling head test method. A representative soil sample that passed through the $4.75 \mathrm{~mm}$ sieve was collected and compacted at optimum moisture content to achieve maximum dry density in a mold having $10 \mathrm{~cm}$ diameter and $12.73 \mathrm{~cm}$ length. After the soil sample was saturated, its permeability was examined by allowing the water to come through it falling from the initial head. The head change and the time taken to the water to come through the sample were recorded until the water begun to flow out of the water bath [30].

\section{E. Unconsolidated Undrained Triaxial Compression Test}

In this paper, remolded cylindrical specimens passed through the $2.36 \mathrm{~mm}$ sieve and having a diameter of $38 \mathrm{~mm}$ and a length twice the diameter $(76 \mathrm{~mm})$ were used. All the test samples were compacted within 6 layers in a manner that can represent the site condition of the soil. Axial load was applied to produce axial strain at a rate of approximately $1 \% / \mathrm{min}$ of the specimen height, which is used as a reference rate in this study. The confining pressure was calculated from the unit weight of the soil, the depth where the samples were collected, and by assuming a coefficient of earth pressure at rest to represent the site that was conveniently used as per Kombolcha town soils behavior. Hence, 5 different strain rates were used, the conventional strain rate of $0.76 \mathrm{~mm} / \mathrm{min}$ and 2 strain rates below and 2 above it. Trials were done during the triaxial test for each selected pit sample. The trials were conducted with increasing strain rate of $0.5 \% \quad(0.38 \mathrm{~mm} / \mathrm{min}), \quad 0.75 \%$ $(0.57 \mathrm{~mm} / \mathrm{min}), 1 \%(0.76 \mathrm{~mm} / \mathrm{min}), 1.25 \%(0.95 \mathrm{~mm} / \mathrm{min})$ and $1.5 \%(1.14 \mathrm{~mm} / \mathrm{min})$ of specimen height with confining pressure of $50 \mathrm{kPa}, 100 \mathrm{kPa}$, and $150 \mathrm{kPa}$ in order to assess the better strain rate for Kombolcha clay soils. A failure envelope was used to determine the shear strength parameters of the test samples [31-33].

\section{RESULTS AND DISCUSSION}

\section{A. Soil Index and Density Results}

As described in Table II, the average moisture content was $31.60 \%$, which lies between stiff and soft clays.

TABLE II. MOISTURE CONTENT, BLUK AND DRY DENSITY, SPECIFIC GRAVITY, AND ATTERBERG'S LIMIT RESULTS

\begin{tabular}{|c|c|c|c|c|c|c|c|c|}
\hline $\begin{array}{c}\text { Pit } \\
\text { No. }\end{array}$ & Location & $\begin{array}{c}\text { Moisture } \\
\text { content, } \\
\text { \% }\end{array}$ & $\begin{array}{c}\text { Bulk } \\
\text { Density, } \\
\text { g/cc }\end{array}$ & $\begin{array}{c}\text { Dry } \\
\text { density, } \\
\text { g/cc }\end{array}$ & $\begin{array}{c}\text { Liquid } \\
\text { limit, } \\
\text { (\%) }\end{array}$ & $\begin{array}{c}\text { Plasticity } \\
\text { Index } \\
\text { (PI \%) }\end{array}$ & $\begin{array}{c}\text { Soil } \\
\text { class }\end{array}$ & $\begin{array}{c}\text { Specific } \\
\text { gravity, } \\
\text { at 20 }\end{array}$ \\
\hline Pt-1 & Kurangoye & 30.12 & 1.75 & 1.34 & 63.68 & 33.11 & $\mathrm{CH}$ & 2.75 \\
\hline Pt-2 & Elkbeye & 29.71 & 1.85 & 1.43 & 56.47 & 31.50 & $\mathrm{CH}$ & 2.72 \\
\hline Pt-3 & Sheshaber & 34.84 & 1.77 & 1.31 & 78.32 & 44.04 & $\mathrm{CH}$ & 2.76 \\
\hline
\end{tabular}

The ranges for bulk density and dry density are 1.75 to 1.85 and 1.31 to $1.43 \mathrm{~g} / \mathrm{cc}$ respectively, which are within the range of silt or clay. The soil grain size analysis ranges results of the obtained samples are 5.82 to $10.14 \%$ sand particles, 25.44 to $32.14 \%$ silt, and 57.43 to $67.25 \%$ the clay fraction. These results show that clay soil is dominantly found, which was also indicated by the results of Atterberg limit results. The liquid limit for these clay soils was found above $50 \%$ and a plasticity index of more than $30 \%$ was obtained. Hence, soils are classified as highly plastic clay $(\mathrm{CH})$ as presented in Table II with an average specific gravity of 2.75 .

\section{B. Compaction and Free Swell Results}

Optimum Moisture Content (OMC, \%) and Maximum Dry Density (MDD, g/cc) of the test pits are listed in Table II. They vary from $22.50 \%$ to $29.80 \%$ and from $1.39 \mathrm{~g} / \mathrm{cc}$ to $1.55 \mathrm{~g} / \mathrm{cc}$ respectively. Maximum dry density of the soil for all pits is greater than the in-place dry density of the soil, which shows that it needs densification to attain maximum density and optimum moisture.

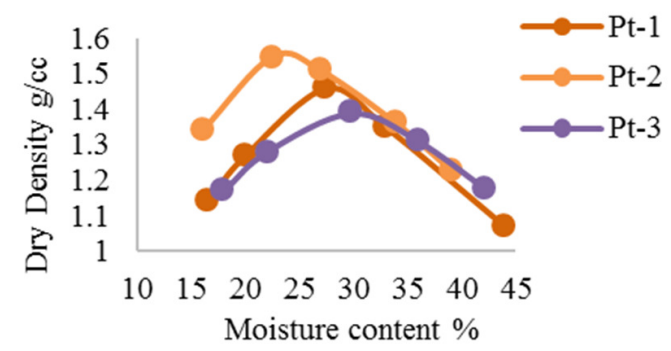

Fig. 1. Standard proctor compaction test results for pit one.

\section{Soil Free Swell, Consolidation, and Permeability Results}

The results of the free swelling of the study area lie within the range from 49.21 to $60.25 \%$, which describes the medium swelling potential (Table III). The magnitude of the compression index varies between 0.25 and 0.29 whereas the swelling index of the clay soils ranges between 0.0169 and 0.0280 . The soils fall within the permeability range of $6.78 \times 10^{-}$ ${ }^{5}$ to $8.09 \times 10^{-6} \mathrm{~cm} / \mathrm{s}$ at $20^{\circ} \mathrm{C}$, which indicates that the area is accumulated by fine soils with low permeability.

TABLE III. COMPACTION PROPERIES, COEFFICIENT OF COMPRESSION AND SWELLING INDECES, AND PERMEABILITY RESULTS

\begin{tabular}{|c|c|c|c|c|c|c|}
\hline Pit No. & $\begin{array}{c}\text { Free } \\
\text { swell, } \\
\mathbf{\%}\end{array}$ & $\begin{array}{c}\text { OMC, } \\
\mathbf{\%}\end{array}$ & $\begin{array}{c}\text { MDD } \\
\mathbf{( g / c c )}\end{array}$ & $\begin{array}{c}\text { Compression } \\
\text { index, Cc }\end{array}$ & $\begin{array}{c}\text { Swelling } \\
\text { index, } \\
\mathbf{C e}\end{array}$ & $\begin{array}{c}\text { Coefficient of } \\
\text { permeability at } \\
\mathbf{2 0} \mathbf{C}, \mathbf{K}(\mathbf{c m} / \mathbf{s})\end{array}$ \\
\hline Pt-1 & 51.53 & 27.50 & 1.46 & 0.27 & 0.0178 & $8.09 \mathrm{E}-06$ \\
\hline Pt-2 & 49.21 & 22.50 & 1.55 & 0.25 & 0.0169 & $6.78 \mathrm{E}-06$ \\
\hline Pt-3 & 60.25 & 29.80 & 1.39 & 0.29 & 0.0280 & $7.19 \mathrm{E}-06$ \\
\hline
\end{tabular}

\section{Unconsolidated Undrained Triaxial Compression Results}

The plots of deviatoric stress to axial strain relationship for the same strain rates under different confining pressure for the 3 test pit samples are shown in Figure 2.

In a similar manner, the stress-strain curves for the not listed strain rates were performed. From these graphs, it was observed that an increase in confining pressure shifts the stressstrain curve upward with different patterns, which illustrate the increase in shear strength up to the failure point. Maximum deviatoric stresses at failure for each strain rate were obtained to determine the shear strength parameters called angle of friction and cohesion. 
(a)

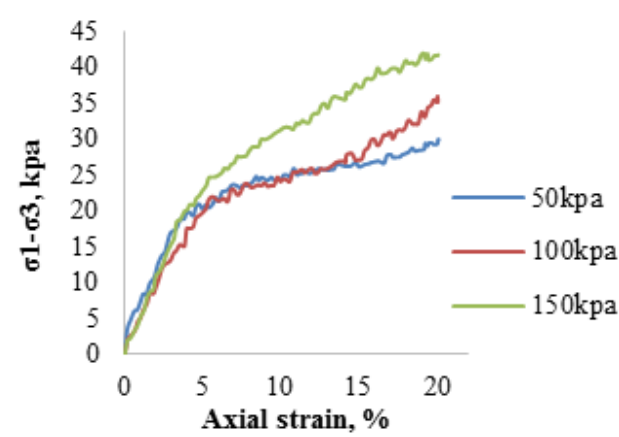

(b)

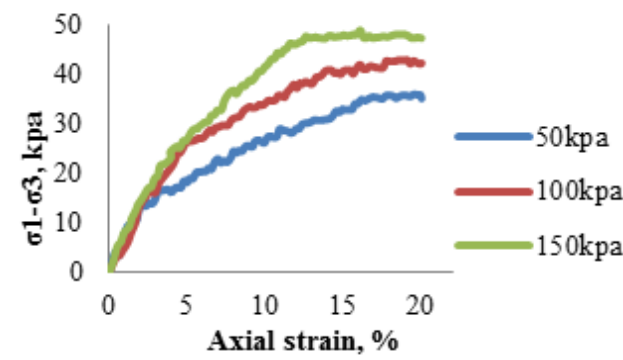

(c)

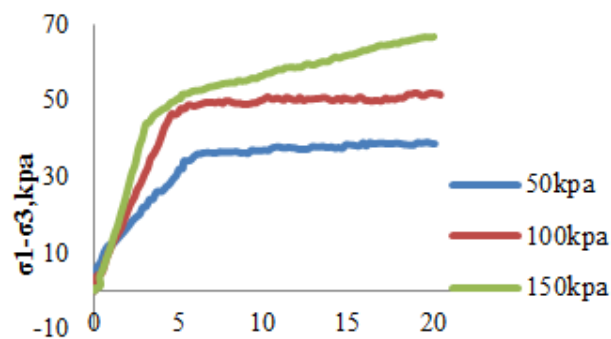

Axial strain, $\%$

(d)

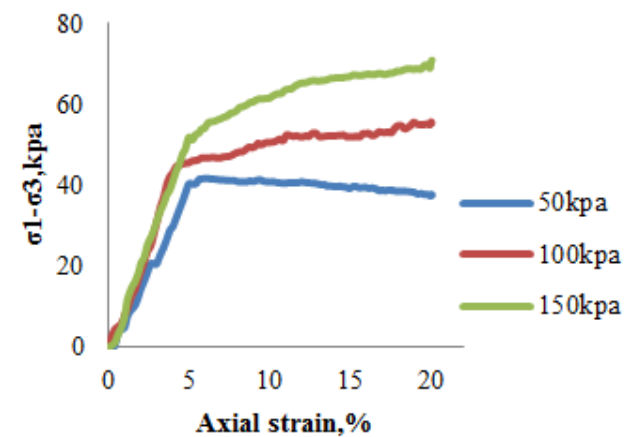

(e)

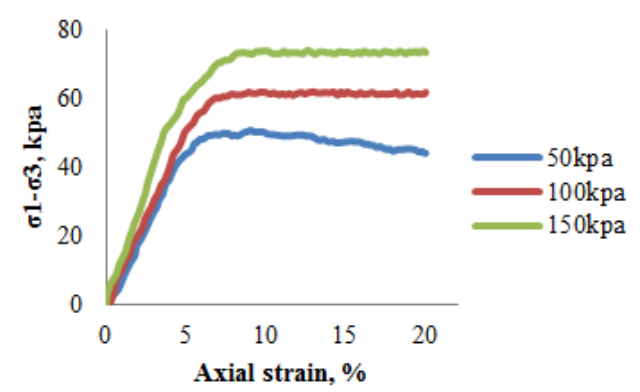

(f)

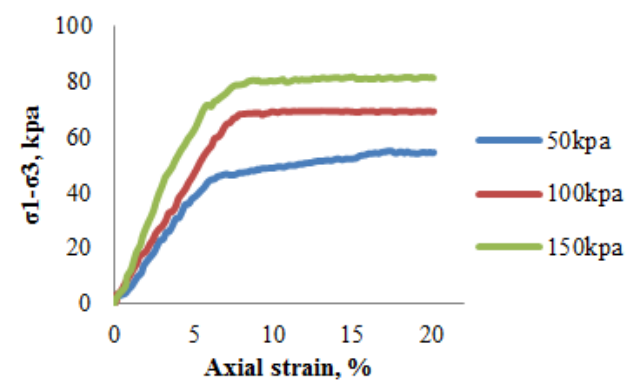

Fig. 2. Deviatoric stress-strain curves for Pt-1 at (a) 0.38, (b) 0.57, Pt-2 at (c) 0.57 and (d) 0.76 , and Pt-3 at (e) 0.95 and (f) $1.14 \mathrm{~mm} / \mathrm{min}$ strain rates under 50,100 , and $150 \mathrm{kPa}$ confining pressure.

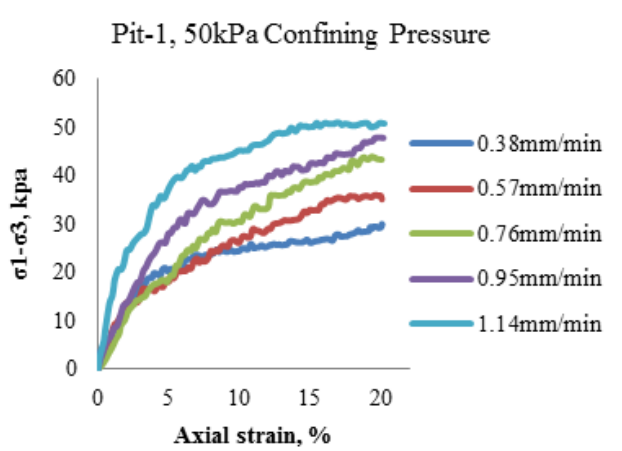

Pit-2, 100kPa Confining Pressure

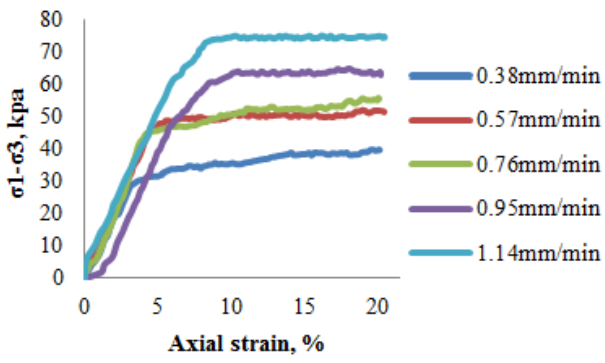

Pit- 2 , at $150 \mathrm{kPa}$ confining pressure

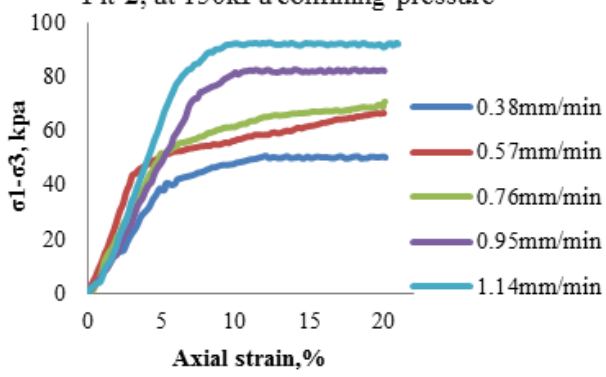

Pit- $3,150 \mathrm{kPa}$ Confining pressure

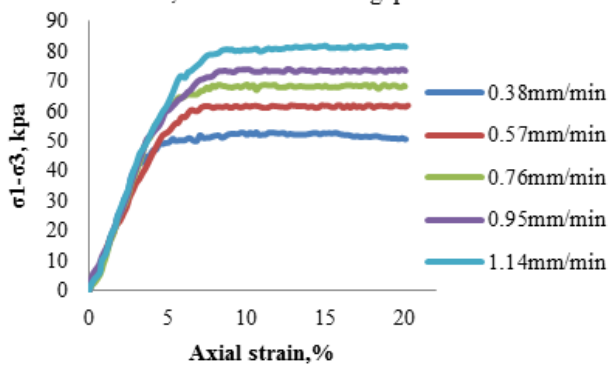

Fig. 3. Stress strain behavior of the three pits under various strain rates. 
Plots of the deviatoric stress versus axial strain with the different strain rate and same confining pressure is shown in Figure 3. Only 4 stress-strain graphs are presented (pit-1 for confining pressure of $50 \mathrm{kPa}$, pit-2 for confining pressure of $100 \mathrm{kPa}$ and $150 \mathrm{kPa}$, and pit-3 for confining pressure of $150 \mathrm{kPa})$. By the same fashion, all 3 pit samples' stress-strain graphs were developed for confining pressures of $50 \mathrm{kPa}$, $100 \mathrm{kPa}$, and $150 \mathrm{kPa}$ under different strain rates. It was revealed that an increase in the strain rate shifts the stressstrain curve upward, which describes the faster strain rate induced increase in deviatoric stress and failure point of the soil under induced pressure. Figure 5 presents the shear strength parameters with the different strain rates for 3 test pit samples. The results were derived from Figures 2 and 3. From Figure 5, it is observed that the cohesion and the angle of internal friction increase when the strain rate increases. Shear parameters angle of friction $\left(\varnothing^{\wedge} 0\right)$ and cohesion $(\mathrm{C}$ in $\mathrm{kPa})$ axes are determined for each stress path at failure strain rates. In a similar way the remaining three samples' determination is done and shear strength parameters are presented in Figure 6. The average angle of friction is equal to $6.81^{\circ}$ and the average cohesion is $13.55 \mathrm{kPa}$ under the described strain rates. These results define clay soil behavior. The soils were weak to bear the imposed load from the buildings in Kombolcha.

(a)

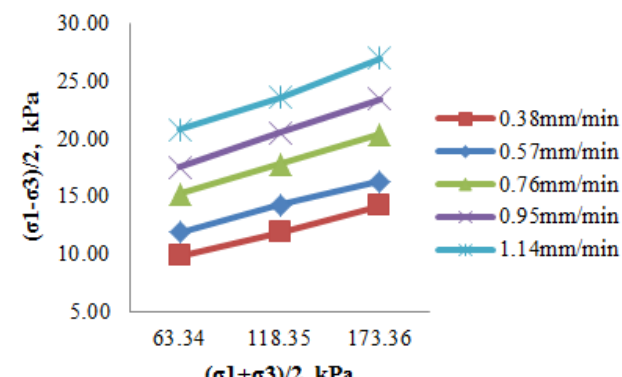

(b)

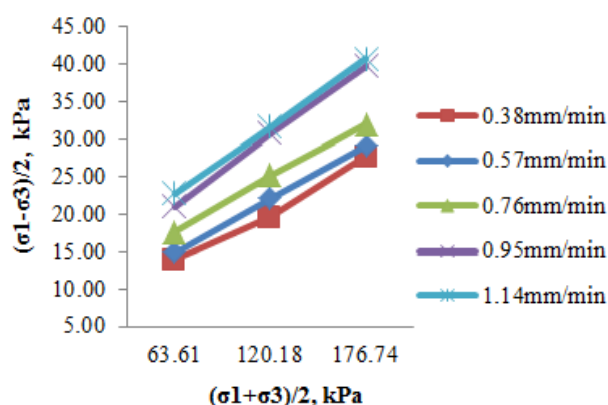

(c)

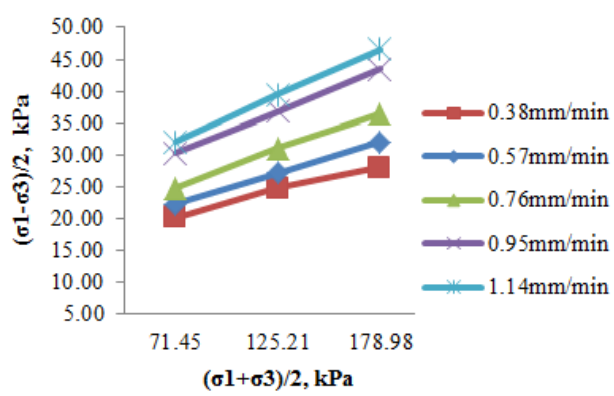

Fig. 4. Normal to shear stress chart at failure and different strain rates for (a) pit-1, (b) pit-2, and (c) pit-3. (a)

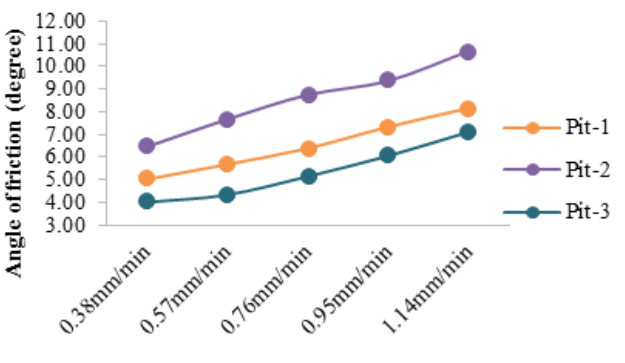

Stress path at failure

(b)

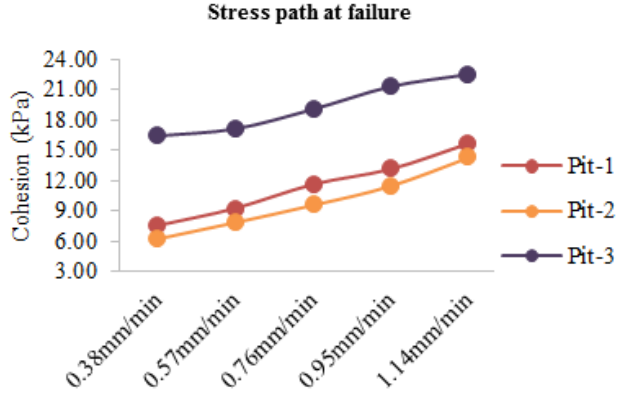

Stress path at failure

Fig. 5. Strain rate effect on: (a) angle of friction and (b) cohesion of soil.

(a)
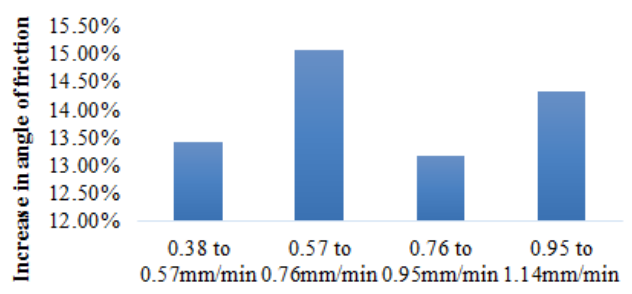

Change in rate of strain

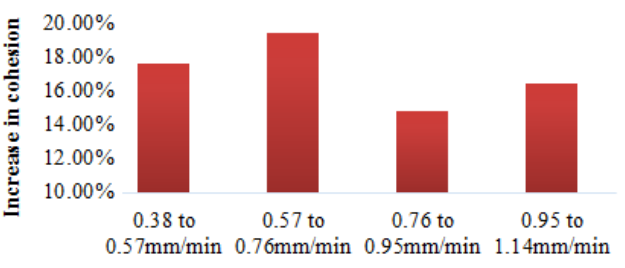

Change in rate of strain

Fig. 6. Increase in soil shear parameters: (a) angle of friction and (b) cohesion.

Accordingly, at higher strain rates $(0.75$ to $1.25 \mathrm{~mm} / \mathrm{min})$ produced in higher undrained shear strength for the clay soil samples, the results show that the failure at the strain rate of $1 \% / \mathrm{min}(0.76 \mathrm{~mm} / \mathrm{min})$ of sample height is uniformly distributed and there is uniform pore pressure distribution throughout the sample height. It was also shown that the angle of friction and the cohesion of soils are inversely related as indicated in Figure 5. As illustrated in Figure 6, the strain rate increased the clay soil shear parameters. These shear strength parameters actually indicate properties of clay soils with high plasticity. Hence, the average angle of friction increased by $13.43 \%, 15.08 \%, 13.18 \%$, and $14.33 \%$ at strain rates of 0.38 to $0.57 \mathrm{~mm} / \mathrm{min}, 0.57$ to $0.76 \mathrm{~mm} / \mathrm{min}, 0.76$ to $0.95 \mathrm{~mm} / \mathrm{min}$ and 0.95 to $1.14 \mathrm{~mm} / \mathrm{min}$ respectively (Figure $6 \mathrm{a}$ )), whereas, the average cohesion increased by $17.67 \%, 19.52 \%, 14.87 \%$ and 
$16.48 \%$ respectively (Figure 6(b)). As indicated in the results of the angle of friction, the change in the strain rate is not significantly affected, but cohesion is slightly more increased with the early strain rates for these soils. The minimum average unconsolidated undrained shear test result for clay soils from Kombolcha occurs for the strain rate of $0.76 \mathrm{~mm} / \mathrm{min}$ to $0.95 \mathrm{~mm} / \mathrm{min}$.

\section{CONCLUSIONS}

The current study described the soils in Kombolcha town as dominantly clay soils. UU triaxial compression tests were performed on the soil at different strain rates. When the strain rate increased, the stress-strain curve moved up and the shear strength also increased. The failure at strain rate $1 \% / \mathrm{min}$ of sample height is uniformly distributed and there was uniform pore pressure distribution throughout the sample height. The increase in undrained shear strength can be associated with the less excess pore water pressure during shearing at faster rates. Test were conducted on the clay soil of Komblocha using strain rates ranging from $0.75 \%$ (rate of $0.57 \mathrm{~mm} / \mathrm{min}$ ) to $1.25 \%$ (rate of $0.95 \mathrm{~mm} / \mathrm{min}$ ) of specimen height of the remolded samples and the average stress-strain and shear strength behaviors of these samples were studied.

\section{ACKNOWLEDGEMENT}

The authors would like to express their gratitude to the Arba Minch University Institute of Technology for its support during this research activity.

\section{REFERENCES}

[1] Y. Wang, J. Li, Q. Jiang, Y. Huang, and X. Li, "Experimental Study on Variation Law and Mechanism of Soil Shear Strength Parameters along the Slope," Advances in Civil Engineering, vol. 2019, Aug. 2019, Art. no. e3586054, https://doi.org/10.1155/2019/3586054.

[2] L. Sun, "Strain Accumulation in Soft Marine Clay due to One-Way Cyclic Load with Variable Confining Pressure," Advances in Civil Engineering, vol. 2021, Apr. 2021, Art. no. e6624270, https://oi.org/10.1155/2021/6624270.

[3] Z. Zhu, C. Zhang, J. Wang, P. Zhang, and D. Zhu, "Cyclic Loading Test for the Small-Strain Shear Modulus of Saturated Soft Clay and Its Failure Mechanism," Geofluids, vol. 2021, Jun. 2021, Art. no. e2083682, https://doi.org/10.1155/2021/2083682.

[4] K. Adugna and Y. Yirga, "Investigation on Engineering Characteristics of Soils. A Case Study in Wolkite University Compound, Ethiopia," Journal of Civil Engineering Research, vol. 10, no. 2, pp. 39-46, 2020.

[5] S. Shimobe and G. Spagnoli, "Some generic trends on the basic engineering properties of fine-grained soils," Environmental Earth Sciences, vol. 78, no. 9, Apr. 2019, Art. no. 281, https://doi.org/ $10.1007 / \mathrm{s} 12665-019-8266-4$.

[6] S. A. Ngah and H. O. Nwankwoala, "Evaluation of Geotechnical Properties of the Subsoil for Shallow Foundation Design in Onne, Rivers State, Nigeria," The International Journal Of Engineering And Science, vol. 2, no. 11, pp. 8-16, Jan. 2013.

[7] J.-S. L'Heureux and T. Lunne, "Characterization and Engineering properties of Natural Soils used for Geotesting," AIMS Geosciences, vol. 6, no. 1, pp. 35-53, 2020, https://doi.org/10.3934/geosci.2020004.

[8] S. Roy and S. K. Bhalla, "Role of Geotechnical Properties of Soil on Civil Engineering Structures," Resources and Environment, vol. 7, no. 4, pp. 103-109, Jan. 2017, https://doi.org/10.5923/j.re.20170704.03.

[9] C. Huang, X. Wang, H. Zhou, and Y. Liang, "Factors Affecting the Swelling-Compression Characteristics of Clays in Yichang, China," Advances in Civil Engineering, vol. 2019, Feb. 2019, Art. no. e6568208, https://oi.org/10.1155/2019/6568208.
[10] W. Mun, T. Teixeira, M. C. Balci, J. Svoboda, and J. S. McCartney, "Rate effects on the undrained shear strength of compacted clay," Soils and Foundations, vol. 56, no. 4, pp. 719-731, Aug. 2016, https://doi.org/ 10.1016/j.sandf.2016.07.012.

[11] S. Robinson and M. J. Brown, "Rate effects at varying strain levels in fine grained soils," in 18th International Conference on Soil Mechanics and Geotechnical Engineering, Paris, France, Sep. 2013, vol. 1, pp. 263 266.

[12] I. B. Gratchev and K. Sassa, "Shear Strength of Clay at Different Shear Rates," Journal of Geotechnical and Geoenvironmental Engineering, vol. 141, no. 5, May 2015, Art. no. 06015002, https://doi.org/10.1061/ (ASCE)GT.1943-5606.0001297.

[13] L. Ma, J. Qi, F. Yu, and X. Yao, "Experimental study on variability in mechanical properties of a frozen sand as determined in triaxial compression tests," Acta Geotechnica, vol. 11, no. 1, pp. 61-70, Feb. 2016, https://doi.org/10.1007/s11440-015-0391-y.

[14] G. Huang, J. Zhou, and X. Gong, "Stress-strain and shear strength properties of rock and soil materials of waste pile in open pit mines," Journal-Zhejiang University Engineering Science, vol. 34, no. 1, pp. 54 59, 2000.

[15] W. Cho and R. J. Finno, "Stress-Strain Responses of Block Samples of Compressible Chicago Glacial Clays," Journal of Geotechnical and Geoenvironmental Engineering, vol. 136, no. 1, pp. 178-188, Jan. 2010, https://doi.org/10.1061/(ASCE)GT.1943-5606.0000186.

[16] L. C. Lollo, "Geotechnical Evaluation of Foundation Soils for a Building (Case Study of a Site in Jimma City, Southwestern Ethiopia)," Journal of Environment and Earth Science, vol. 6, no. 3, pp. 95-98, 2016.

[17] A. Shrestha, A. Jotisankasa, S. Chaiprakaikeow, S. Pramusandi, S. Soralump, and S. Nishimura, "Determining Shrinkage Cracks Based on the Small-Strain Shear Modulus-Suction Relationship," Geosciences, vol. 9, no. 9, Sep. 2019, Art. no. 362, https://doi.org/10.3390/ geosciences 9090362 .

[18] S. Fekadu, "Shear Strength and Consolidation Characteristics of Lateritic Soils: A Case of Asela Town, Oromia Regional State, Ethiopia," International Journal of Environmental Monitoring and Analysis, vol. 9, no. 1, pp. 21-28, Mar. 2021, https://doi.org/10.11648/j.ijema.20210901. 13.

[19] M. A. Adigun, K. A. Olatunji, F. O. Alaboru, and A. B. Ogunbajo, "Evaluation of Sub-Soil Geotechnical Properties for Shallow Foundation and Pavement Design in LASPOTECH, Ikorodu Campus, Lagos State, Nigeria," IOSR Journal of Mechanical and Civil Engineering, vol. 11, no. 6, pp. 40-47, Dec. 2014, https://doi.org/10.9790/1684-11644047.

[20] J. Z. Zhang, L. C. Miao, and H. J. Wang, "Methods for characterizing variability of soil parameters," Chinese Journal of Geotechnical Engineering, vol. 31, no. 12, pp. 1936-1940, 2009.

[21] A. Teklay, M. Haile, A. Teferra, and E. J. Murray, "The effect of sample preparation and testing procedure on the geotechnical properties of tropically weathered residual laterite soils of Ethiopia," Zede Journal, vol. 33, pp. 45-62, 2015.

[22] C. M. Chan and H. Y. Yong, "Comparing the Thixotropic and Lightly Solidified Hardening Behavior of a Dredged Marine Clay," Engineering, Technology \& Applied Science Research, vol. 4, no. 5, pp. 706-710, Oct. 2014, https://doi.org/10.48084/etasr.494.

[23] M. Mohammadi, M. Shabanpour, M. H. Mohammadi, and N. Davatgar, "Characterizing Spatial Variability of Soil Textural Fractions and Fractal Parameters Derived from Particle Size Distributions," Pedosphere, vol. 29, no. 2, pp. 224-234, Apr. 2019, https://doi.org/10.1016/S10020160(17)60425-9.

[24] F. Luo, Q. Luo, L. Jiang, Y. Lyu, and D. Kong, "Influence of variation levels of soil strength indexes on the value of slope stability safety factor," vol. 37, pp. 77-83, Aug. 2015, https://doi.org/10.11835/j.issn. 1674-4764.2015.04.010.

[25] J. James and P. K. Pandian, "Plasticity, Swell-Shrink, and Microstructure of Phosphogypsum Admixed Lime Stabilized Expansive Soil," Advances in Civil Engineering, vol. 2016, Jul. 2016, Art. no. e9798456, https://doi.org/10.1155/2016/9798456.

[26] H. Sellaf, H. Trouzine, M. Hamhami, and A. Asroun, "Geotechnical Properties of Rubber Tires and Sediments Mixtures," Engineering, 
Technology \& Applied Science Research, vol. 4, no. 2, pp. 618-624, Apr. 2014, https://doi.org/10.48084/etasr.424.

[27] F. S. Khan, S. Azam, M. E. Raghunandan, and R. Clark, "Compressive Strength of Compacted Clay-Sand Mixes," Advances in Materials Science and Engineering, vol. 2014, Nov. 2014, Art. no. e921815, https://doi.org/10.1155/2014/921815.

[28] T. A. Rind, H. Karira, A. A. Jhatial, S. Sohu, and A. R. Sandhu, "Particle Crushing Effect on The Geotechnical Properties of Soil," Engineering, Technology \& Applied Science Research, vol. 9, no. 3, pp. 4131-4135, Jun. 2019, https://doi.org/10.48084/etasr.2730.

[29] L. Zhang, F. Dang, J. Gao, and J. Ding, "Measurement and Investigation on 1-D Consolidation Permeability of Saturated Clay considering Consolidation Stress Ratio and Stress History," Geofluids, vol. 2021, Mar. 2021, Art. no. e6616331, https://doi.org/10.1155/2021/6616331.

[30] S. Nazari, M. Hassanlourad, E. Chavoshi, and A. Mirzaii, "Experimental Investigation of Unsaturated Silt-Sand Soil Permeability," Advances in Civil Engineering, vol. 2018, Jan. 2018, Art. no. e4946956, https://doi.org/10.1155/2018/4946956.

[31] J. Ding, X. Feng, Y. Cao, S. Qian, and F. Ji, "Consolidated Undrained Triaxial Compression Tests and Strength Criterion of Solidified Dredged Materials," Advances in Civil Engineering, vol. 2018, Oct. 2018, Art. no. e9130835, https://doi.org/10.1155/2018/9130835.

[32] S. Sun, F. Zhu, J. Wei, W. Wang, and H. Le, "Experimental Study on Shear Failure Mechanism and the Identification of Strength Characteristics of the Soil-Rock Mixture," Shock and Vibration, vol. 2019, Jul. 2019, Art. no. e7450509, https://doi.org/10.1155/2019/ 7450509.

[33] M. Zhao, G. Liu, L. Deng, and Y. Li, "Optimizing the Compaction Characteristics and Strength Properties of Gravelly Soils in terms of Fine Contents," Advances in Materials Science and Engineering, vol. 2021, Jan. 2021, Art. no. e6634237, https://doi.org/10.1155/2021/6634237. 